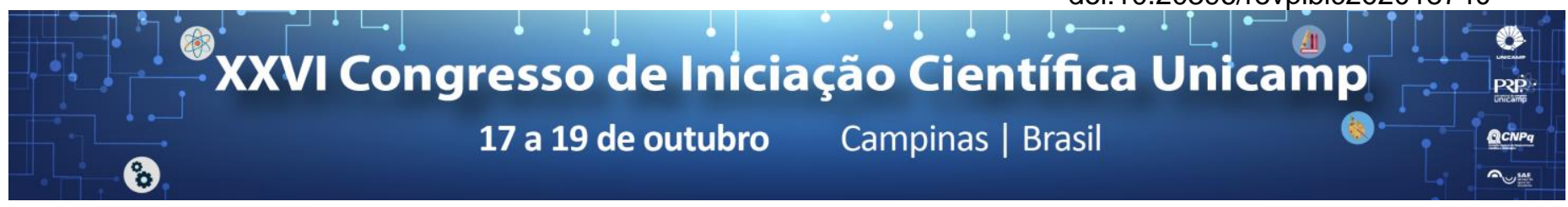

\title{
Percurso de formação profissional de treinadores de basquetebol.
}

\author{
Kaique B. C. Favari, Larissa R. Galatti.
}

\begin{abstract}
Resumo
A iniciação esportiva é um importante momento para o resultado dos praticantes no futuro e para isso é necessário uma boa formação de treinadores. Portanto, o estudo tem como objetivo analisar o percurso de formação dos treinadores de basquetebol de categorias de base analisando as suas aprendizagens adquiridas. Para a coleta de dado foi utilizada a entrevista semiestruturada e para a análise a Análise Temática. Como conclusão, identificamos um leque alargado de aprendizagens adquiridas ao longo da formação dos treinadores, entendendo assim, que não existe um perfil único e ideal de treinador como ilustra o equilíbrio de aprendizagens citadas; até mesmo os treinadores muito experientes na prática, estão em constante desenvolvimento promovendo uma melhor forma de ensino.
\end{abstract}

\section{Palavras-chave:}

Treinador, Aprendizagens, Basquetebol.

\section{Introdução}

O papel do treinador como mediador quando bem executado pode ser um grande influenciador para obterse bons resultados e influenciar na formação dos indivíduos. A pesquisa de Rodrigues et al. (2017), relatou que as aprendizagens formais e não formais agregam na atuação dos treinadores, contudo as aprendizagens informais formam as base do conhecimento.

A aprendizagem formal ocorre em instituições que oferecem currículos padronizados; não formal ocorre por voluntariedade em atividades sistemáticas; informal ocorre fora das instituições de ensino com a aquisição e acúmulo de conhecimento, habilidade, valores e atitudes ao longo da vida (RODRIGUES; PAES; SOUZA NETO, 2016).

Diante disso, este estudo tem como objetivo analisar as aprendizagens adquiridas durante 0 percurso de formação dos treinadores de basquetebol que atuam em categorias formadoras. E além disso, comparar se há convergências e/ou divergências quando comparamos as idades e gêneros dos treinadores.

Para a coleta de dado foi utilizado a entrevista semiestruturada e para a análise a Análise Temática (BRAUN, CLARK, WEATE, 2016). Entrevistamos 4 treinadores com menos de 30 anos, 4 treinadores entre 30 e 50 anos e 4 com mais de 50 anos, além disso, cada grupo tinha dois homens e duas mulheres.

\section{Resultados e Discussão}

A discussão prima por deferir a importância das aprendizagens formais, não formais e informais quando integradas de modo a levar à formação dos treinadores entrevistados.

Cabe ressaltar que os sujeitos entrevistados mostraram uma variedade de aprendizagens adquiridas, sendo possível verificar convergências e divergências entre as idades e os gêneros dos mesmos. Primeiramente, todos são graduados em Educação Física, e a mesmas auxiliou para a profissão, apesar de não haver aprofundamento na modalidade (BRASIL et al., 2015). Além disso, todos buscaram cursos, clinicas e workshops dentro e fora da faculdade para se aperfeiçoarem.

O número maciço de treinadores ex atletas não foi representado nesse estudo, de 12 entrevistados, apenas 3 foram atletas profissionais. E por fim, todos citaram adquirir experiências no seu dia a dia com os desafios enfrentados que podem favorecer sua eficácia (TOZZETO et al., 2017).

Diante das divergências, somente treinadores com idade inferior a 30 anos fizeram intercâmbios em times internacionais. $E$ notamos um engajamento maior das mulheres quando envolve estudos na Universidade, apenas mulheres relataram fazer monitoria e participar de grupos de estudos, e há uma superioridade delas em relação à pós graduação e/ou especialização revelando interesse em se aprimorar (SCHIAVON et al., 2014), todas mulheres fizeram/fazem contra apenas dois homens.

\section{Conclusões}

Neste estudo, identificamos um leque alargado de aprendizagens adquiridas ao longo da formação dos treinadores, entendendo assim, que não existe um perfil único e ideal de treinador como ilustra o equilíbrio de aprendizagens citadas. Concluímos que até mesmo os treinadores muito experientes na prática estão em constante desenvolvimento promovendo uma melhor forma de ensino.

\section{Agradecimentos}

Conselho Nacional de Desenvolvimento Científico e Tecnológico - CNPQ.

BRASIL, V. Z. et al. A formação profissional para treinadores de surf no Brasil. In: NASCIMENTO, J. V. et al. Educação física e esporte: convergindo para novos caminhos. Florianópolis: Udesc, 2015. p. 357-381.

BRAUN, V., CLARKE, V., WEATE, P. Using Thematic Analysis in Sport and Exercise Research. Routledge Handbook of Qualitative Research in Sport and Exercise, 2016.

RODRIGUES, H. A. et al. As fontes de conhecimento dos treinadores de jovens atletas de basquetebol. Motrivivência, Santa Catarina, v. 29, n. 51, p.100-118, 20 jul. 2017.

RODRIGUES, H. A.; PAES, R. R.; NETO, S. S. A socialização profissional do treinador esportivo como um processo formativo de aquisição de saberes. Revista Movimento, Porto Alegre, v. 22, n. 2, p.509-521, abr. - jun. 2016.

SCHIAVON, L. M. et al. Análise da formação e atualização dos técnicos de ginástica artística do estado de São Paulo. Pensar A Prática, Goias, v. 17, n. 3, p.618-635, 9 set. 2014.

TOZETTO, A. V. B. et al. Football coaches' development in Brazil: a focus on the content of learning. Motriz: Revista de Educação Física, [s.1.], v. 23, n. 3, p.1-9, 21 dez. 2017. FapUNIFESP (SciELO). 